\title{
PERANCANGAN SISTEM INFORMASI AKADEMIK BERBASIS WEB DI MTS NURUL MUHSININ BATUJAI LOMBOK TENGAH
}

\author{
Nujumuddin \\ Unversitas Islam Negeri Mataram \\ nujumudin14@gmail.com
}

\begin{abstract}
Abstrak: Pendidikan adalah jembatan dalam pengembangan retorika dan konstruksi sosial. Pendidikan mempengaruhi perkembangan dan pertumbuhan manusia dan perkembangan peradaban ke arah yang lebih baik. Oleh karena itu, dibutuhkan peran semua pihak termasuk institusi pendidikan perguruan tinggi dalam mengembangkan pendidikan. Tujuan kegiatan pengabdian ini adalah untuk memberikan pengetahuan, meningkatkan pengalaman dan penguasaan teknologi informasi kepada sumber daya manusia di MTs Nurul Muhsinin. Pengabdian ini dilaksanakan melalui tahapan observasi, sosialisasi, pelatihan, dan pendampingan. Hasil pengabdian menunjukkan bahwa program pelatihan dan pendampingan yang dilakukan dapat meningkatkan pengetahuan dan pengalaman guru dalam merancang dan mendesain website sebagai bagian dari sistem informasi yang bermanfaat bagi pengembangan sekolah.
\end{abstract}

Kata kunci: perancangan, sistem informasi, website

\begin{abstract}
Education is a bridge in the development of rhetoric and social construction. Education influences human development and growth and the development of civilization in a better direction. Therefore, the role of all parties, including tertiary educational institutions, is needed in developing education. The purpose of this community service program is to provide knowledge, enhance the experience and mastery of information technology to human resources at MTs Nurul Muhsinin. This program is carried out through stages of observation, socialization, training, and mentoring. The results show that training and mentoring programs carried out can increase the knowledge and experience of teachers in designing and designing websites as part of an information system that is beneficial for school development.
\end{abstract}

Keywords: design, system of information, website

\section{Pendahuluan}

Di era globalisasi pendidikan merupakan salah satu kebutuhan, sehingga tidak dapat dipisahkan dari kehidupan sehari hari. Ketertinggalan bangsa Indonesia di bidang pendidikan dibandingkan negara-negara tetangga menyebabkan pemerintah terdorong untuk memacu din' untuk memiliki standar in.ternasional. Dorongan tersebut bahkan dicantumkan di dalam UU No. 20 Tahun 2003 tentang Sisdiknas pasal 50 ayat (3) yang berbunyi, "Pemerintah dan/atau pemerintah daerah menyelenggarakan sekurang-kurangnya satuan pendidikan pada semua jenjang pendidikan, untuk dikembangkan menjadi satuan pendidikan yang bertaraf internasional.

Saat ini pengolahan data siswa, pengolahan informasi nilai, pengolahan jadwal mengajar, di MTs Nurul Muhsinin, sebagian besar belum berjalan secara cepat dan tepat, seperti pencarian data siswa masih harus membuka lembaran lembaran arsip di bagian kesiswaan, pengumumanpengumuman seperti jadwal mengajar dan hal penting lainnya telah memenuhi papan pengumuman sekolah, serta penghitungan nilai masih memakan waktu yang lama.

Menyadari hal tersebut, madrasah sebagai agen perubahan di masyarakat harus senantiasa melakukan perubahan sesuai dengan dinamika perkembangan masyarakat dalam 
perkembangan IPTEK. Teknologi Informasi berbasis komputer adalah salah satu media yang cukup efektif dalam mengelola sistem informasi akademik madrasah. Penggunaan Internet dewasa ini juga mulai meningkat di kalangan pendidikan, penggunaan inii tidak hanya sekedar mencari informasi di internet saja, tetapi juga sudah menerapkan teknologi Internet ini.

Undang-undang sisdiknas Nomor 20 Tahun 2003 mengamanatkan bahwa sebagai media publikasi madrasah dalam meningkatkan mutu dan kualitas madrasah. Salah satu upaya yang bisa dijadikan sebagai program unggulan best Practice sebuah institusi pendidikan madrasah adalah pembuatan website Madrasah, dengan domain sch.id yang dipandang sebagai jembatan emas untuk meraih masa depan yang gemilang, terlebih di dalam website ini terdapat sistem yang memungkinkan pengawasan nilai siswa sebagai bahan evaluasi yang dapat dipantau oleh orang tua wali diberbagai. tempat yang pengolahannya dapat dilakukan secara online. Selain itu juga berbagai informasi madrasah yang menjadi daya tarik masyarakat dalam memandang citra madrasah.

Kegiatan Akademik dikenal sebagai siklus kegiatan pembelajaran yang dimulai dari siswa, sebuah proses penerimaan siswa sampai siswa menyelesaikan studi mereka. Menurut Fadjar, akademik adalah keadaan orang-orang bisa menyampaikan dan menerima gagasan, pemikiran, ilmu pengetahuan, dan sekaligus dapat mengujinya secara jujur, terbuka, dan leluasa. Sedangkan menurut Satoto, perangkat lunak yang digunakan untuk menyajikan infornasi dan menata administrasi yang berhubungan dengan kegiatan akademis dibuat sistem informasi akademik'.

Data akademik tersebut secara umum meliputi data masukan terdiri dari: data siswa, data guru, data jadwal mengajar, daftar nilai mahasiswa, data pendaftar siswa baru, dan keluaran (output) dari Sistem Informasi Akademik yaitu daftar nama siswa, daftar nama guru, jadwal mengajar, daftar nilai siswa, daftar nama pendaftar.

Secara garis besar untuk membangun sebuah sistem informasi akademik harus mempunyai komponen yang sama dengan sistem informasi secara umum. yaitu: komponen input, komponen model, komponen basis data, dan komponen output. Perbedaan komponenkomponen ini antar sistem-sistem i.nformasi lainnya adalah konteks letak dart sistem informasinya. Komponen Input Akademik, sistem informasi akademik mengumpulkan data yang berkaitan dengan pengelolaan data misalnya data siswa, data guru. Komponen model akademik, model digunakan untuk menghasilkan informasi yang relevan yang sesuai dengan kebutuhan pemakai sistemnya. Model merupakan cetakan yang merubah bentuk input menjadi output. Model di sistem informasi akademik banyak digunakan untuk menghasilkan informasiinformasi tentang pengelolaan data siswa, guru. Komponen basis data akademik, data yang digunakan untuk output berasal dari database.

Komponen berikutnya adalah Komponen Output Akademik, tiap subsistem output menyediakan informasi tentang subsistem itu sebagai bagian dari bauran. Beberapa keuntungan yang dapat diperoleh dengan penerapan Sistem informasi Akademik ini adalah : Kernudahan bagi siswa untuk memperoleb informasi tanpa harus melakukan interaksi langsung dengan bagian administrasi karena informasi tersebut dapat diperoleh dengan melakukan pencarian data melalui komputer yang terkoneksi secara internet. 
Kemudahan bagi setiap bagian bagian dikarenakan berkurangnya interaksi secara langsung dan lebih dilakukan interaksi terhadap data-data yang diinputkan oleh siswa yang merupakan kebutuhan untuk proses pengolahan data. Penyimpanan data yang terstruktur dikarenakan Sistem Infornasi Akademik menggunakan database yang tersimpan didalam komputer.

Updating informasi antara bagian administrasi akademik maupun dengan bagian keuangan yang merupakan validasi untuk status siswa sehingga dapat melakukan kegiatan belajar mengajar, dimana terjadi interaksi data secara langsung tanpa memerlukan update data secara manual. Update data dari Sistem keuangan dan sistem akademik merupakan proses penting dimana proses ini mengupdate status mahasiswa dalam interval waktu tertentu.

Kemudahan bagi pengajar untuk melakukan kegiatan belajar mengajar dimana pada komponen Front End Web dan komponen Back End Web dapat membantu para pengajar untuk menyampaikan infonnasi secara on-line dan menerima informasi secara on-line dari siswa. Pada sistem ini dapat mereduksi waktu yang dilakukan pada sistem akademik secara manual. Pembuatan website madrasah menjadi salah satu pilihan ketika masyarakat juga mulai terbiasa dengan memanfaatkan teknologi berbasis internet. Untuk itu, sudah selayaknya lembaga pendidikan me.miliki website sebagai sarana komunikasi. antara guru, siswa dan wali murid. Di samping itu, Website Madrasah juga bisa menjadi pusat informasi bagi pengunjung dan mereka yang ingin melanjutkan jenjang pendidikannya lebih tinggi.

Berdasarkan pemaparan di atas, maka system infonnasi akademik berbasis website di MTs Nurul Muhsinin merupakan jawaban atas tantangan perkembangan zaman di era teknologi.

\section{Metode}

Pengabdian ini dilaksanakan melalui proses observasi dan pengenalan, sosialisasi, dan Focus Group Discussion (FGD), pelatihan, dan pendampingan. Pengenalan situs pengabdian dilakukan melalui pengamatan secara langsung oleh pengabdi. Adapun FGD dilakukan dengan melakukan diskusi dengan kepala madrasah dan pimpinan yayasan.

\section{Hasil dan Pembahasan}

\section{Tahapan Pengabdian Masyarakat}

Sebagai pengajar di Kampus, dosen memiliki tugas tridhrama yang harus dilaksanakan secara integralistik. Pendidikan, penelitian dan pengabdian harus seiring dan seragam. Dibidang pendidikan dilaksanakan melalui tugas pembelajaran sedangkan dibidang penelitian melalui research lapangan dan dibidang pengabdian melalui research penguatan kapasitas sumber daya manusia, lembaga dan lain sebagainya. Pengabdian yang dirancang adalah yang memiliki posisi keakuratan dan kebermaknaan dalam kehidupan masyarakat. Pengabdian ini diharappkan dapat memiliki manfaat yang baik, menjadi tambahan pengetahuan bagi guru dan lain sebagainya.

Adapun tema pengabdian bertema "Perancangan Sistem Informasi Akademik Web di MTs Nurul Muhsinin Batujai Lombok Tengah". Tujuan pelaksanaan pengabdian ini adalah untuk 
meningkatkan pengetahuan, pengalaman dan mendekatkan sumber daya MTs dengan teknologi informasi yang ada. Pelaksanaannya dilakukan pada bulan Juli- Oktober 2018.

Pelaksanaan pengabdian dilakukan dengan berbagai tahapan-tahapan yang dapat dirancang dan diaplikasikan secara sistematis. Untuk memudahkan pengabdi dalam menjalankan tugas pengabdian tersebut, Mekanisme pelaksanaan kegiatan ini melewati lima tahap kegiatan yaitu; (1) observasi dan pengenalan madrasah, (2) Sosialisasi dan Focus Group Discussion, (3) pengenalan komponen komputer dan WEB, (4) Pendampingan penguatan program, dan (5) Monitoring Evaluasi. Untuk lebih jelasnya kegiatan di setiap tahapan tersebut di uraikan lebih rinci di bawah ini

\section{Observasi dan Pengenalan Madrasah}

Pengenalan situs pengabdian adalah sebuah keniscayaan untuk memulai sebuah kegiatan pengabdian. Sebagaimana definisi observasi merupakan pengalaman dan pencatatan secara sistematik terhadap gejala yang tampak pada objek penelitian ${ }^{1}$. Observasi dilakukan secara sengaja dan sistematis mengenai fenomena sosial dan gejala-gejala psikis untuk kemudian dilakukan pencatatan ${ }^{2}$. Dengan observasi akan dilakukan pengamatan dan pencatatan yang sistematis terhadap gejala-gejala yang dikaji. Kegiatan observasi pada aktivitas pengamatan dan pencatatan bertujuan mengecek kebaruan dari program yang sedang di kembangkan.

Observasi dilakukan sebelum menyusun proposal pengabdian. Observasi dilakukan diawali dari kunjungan pengabdi ke bakal lokasi pengabdian yaitu MTs. Nurul Muhsinin. Madrasah ini terletak di Dusun Jomang. Desa Batujai Kecamatan Praya Barat Kabupaten Lombok Tengah. Madrasah ini terletak antara Hotel Grand Royal Batujai dan Kuburan Jomang Lauq. Kegiatan observasi dilaksanakan pada bulan Maret 2018.

Berdasarkan hasil observasi diperoleh beberapa informasi bahwa proses belajar mengajar di MTs Nurul Muhsinin mengalami kondisi sebagai berikut:

a. Sebagian besar guru melaksanakan pembelajaran masih bersifat konvensional, artinya masih mengandalkan metode ceramah dan sebagian guru juga telah menggunakan pembelajaran sesekali menggunakan LCD.

b. Fasilitas pembelajaran yang digunakan guru sebagiannya sudah menggunakan komputer/laptop, hal ini memungkinkan bagi yayasan untuk pengembangan kedepan lebih baik.

c. Nurul Muhsinin memiliki posisi yang strategis diantara hotel yang satu-satunya di Desa Batujai. Dimana keberadannya dapat menjadi pemicu semangat santri untuk memahami teknologi.

d. Guru-guru di MTs Nurul Muhsini sering mendapat pelatihan dibidang pembelajaran.

Selain keunggulan di atas juga memiliki beragam kelemahan sebagai berikut:

a. Sistem akademiknya masih offline (manual).

b. Kebanyakan guru belum mengenal Sistem informasi akademik online.

c. Penataan administrasi masih manual, dan

${ }^{1}$ Amirul Hadi dan Haryono, Metodologi Penelitian Pendidikan. (Bandung : Pustaka Setia, 2005), h.

2 Muhammad Nazar, Metode Penelitian. (Jakarta: Galih Indonesia, 1998), h. 211 
d. Guru-guru MTs Nurul Muhsinin sama sekali belum pernah mendapat pelatihan dibidang website.

Dari beragam persoalan tersebut, yang menjadi konsen pengabdi adalah tentang bagaimana meracik atau mengenalkan rancangan web kepada guru sebagai fokus utama. Ratarata guru memiliki notebook yang dapat digunakan untuk mengakses informasi online.

Setelah melakukan observasi tentang persoalan yang dihadapi guru baik dalam hal pengadministrasian pendidikan maupun pembelajaran, maka pengabdi tertarik mengeksplorasi sistem pengadministrasiannya. Sistem pengadministrasian yang akan dikembangkan adalah sistem informasi akademik berbasis WEB. Dalam pelaksanaannya, peneliti juga mendapati beberapa kendala diantaranya belum tersedianya wifi yang memadai. Oleh karena itu, hal ini harus menjadi pembicaraan dengan pihak yayasan tentang bagaimana pengadaannya.

\section{Sosialisasi dan Focus Group Discussion}

Sosialisasi adalah proses penanaman atau transfer kebiasaan atau nilai dan aturan dari satu generasi ke generasi lainnya dalam sebuah kelompok atau masyarakat. Sosialisasi dapat membantu individu dalam meraih identitas dirinya baik secara fisik maupun mental. Sosialisasi membantu setiap individu atau kelompok dalam mengembangkan potensi humanistiknya, dan juga membantu individu atau kelompok untuk belajar bagaimana hidup dalam masyarakat sosial. Sosialisasi memenuhi kebutuhan dasar manusia untuk bertahan dalam kehidupan sosial. Sosialisasi membantu individu atau kelompok dalam mengimitasi kebudayaan ${ }^{3}$.

Menterjemahkan maksud sosialisasi di atas, maka langkah selanjutnya yang dilakukan adalah menemui pengurus yayasan Nurul Muhsinin, khususnya Kepala MTs. Nurul Muhsinin yaitu, Bapak Ratiah, M. Pd. Kegiatan sosialisasi dilaksanakan pada tanggal 7 Juli 2018. Adapun kegiatan sosialisasi dan FGD dilaksanakan melalui tahapan sebagai berikut:

a. Menemui secara langsung Kepala MTs. Nurul Muhsinin dan mendiskusikan tentang keunggulan dan kelemahan yang dihadapi oleh MTs. Selama ini.

b. Hasil diskusi kemudian dituangkan dalam kegiatan FGD.

c. Membuat undangan FGD kepada para guru yang ada di MTs. Nurul Muhsinin,

d. Menyepakati pelaksanaan FGD dengan jumlah undangan yang telah disepakati, dalam hal ini undangan berjumlah 15 orang.

Setelah menetapkan hari pelaksanaan FGD, selanjutnya adalah pelaksanaan FGD. Kegiatan FGD dihadiri oleh 15 orang sesuai dengan undangan yang ada. Dalam kegiatan ini, guru banyak menyampaikan hal sebagai berikut:

Aisyah, guru MTs. Mengatakan bahwa selama ini kami melakukan sistem pengadministrasian dilakukan secara manual. Artinya, penulisan raport dan administrasi lainnya dilakukan secara offline. Untuk itu, kami sangat menginginkan adanya alternatif terobosan baru yang inovatif untuk mempermudah pekerjaan menjadi lebih cepat.

Memperkuat pernyataan Aisyah, kemudian dipertegas oleh Kepala MTs. Yang mengiyakan bahwa benar selama ini sistem pengadministrasian madrasah berlangsung manual. Namun

\footnotetext{
${ }^{3} \mathrm{http}: / /$ www.sumberpengertian.co/pengertian-sosialisasi-lengkap. diakses tanggal 05/10/2018. jam 21.17 WITA
} 
diyakininya, bahwa manualitas sistem tidak mengurangi makna dari substansi yang sesungguhnya.

Pelaksanaan sosialisasi dihujani berbagai macam pertanyaan dan penjelasan mengenai kondisi sebenarnya madrasah. Sosialisasi adalah merupakan proses yang mengacu pada persiapan pengajaran tentang bagaimana melakukan usaha, termasuk bagaimana memahami dan menerima nilai-nilai, norma, dan keyakinan.

Selanjutnya adalah kesempatan bagi pengabdi untuk memperkenalkan diri, tujuan dan maksud kedatangan ke madrasah. Pada kesempatan ini, kunjungan personal pengabdi ke lokasi, dilakukan melalui pertemuan personal kepada kepala madrasah dan guru. Tindak lanjut dari kegiatan sosialisasi adalah memberikan amahah kepercayaan bagi sebagian guru untuk menjadi pembantu lapangan, mengkoordinir program yang akan dilaksnakan.

Setelah pembantu lapangan terbentuk, selanjutnya pengabdi melakukan koordinasi dengan pembantu lapangan. Aktivitas sosialisasi diawali dikawal oleh pembantu lapangan, yang kemudian disusul dengan program FGD. Kegiatan ini dilaksanakan pada tanggal 08 Juli 2018.

Proses FGD dilakukan dalam dua pertemuan. FGD dilaksanakan tanggal 10 dan 11 Juli 2018. Pada pertemuan ini banyak membicarakan tentang keterampilan guru mengoperasikan komputer, urgensi program pelatihan dan manfaatnya bagi guru. Guru sebagai pengajar memiliki peran vital dalam menjalankan tugas pengajaran, juga termasuk tugas administrasi seperti administrasi persiapan perangkat pembelajaran maupun jadwal pelajaran.

Sesi kedua FGD dihadiri oleh kurang lebih 10 guru. Dalam penjelasannya pengabdi menjelaskan banyak hal diantaranya adalah sebagai pondok pesantren yang berkemajuan, tentu perlu ada deseminasi informasi bagi masyarakat agar dapat menjalankan tugas penyebarluasan informasi yang dapat dilakukan secara masif. Lebih jelasnya mengenai materi FGD saat diskusi mengikuti tahapan sebagai berikut:

\section{Pengantar Pengabdi Tentang Rencana Program Pengabdian}

Kegiatan pengabdian diawali penyampaian tentang pentingnya melakukan inovasi terhadap perubahan sistem pendidikan. inovasi karena ada permasalahan yang harus diatasi, dan upaya mengatasi permasalahan tersebut melalui inovasi (seringkali disebut dengan istilah "pembaharuan" meskipun istilah ini tidak identik dengan inovasi). Inovasi ini harus merupakan hasil pemikiran yang original, kreatif, dan tidak konvensional. Penerapannya harus praktis di mana di dalamnya terdapat unsur-unsur kenyamanan dan kemudahan. Semua ini dimunculkan sebagai suatu upaya untuk memperbaiki situasi / keadaan yang berhadapan dengan permasalahan.

Inovasi adalah sebagai alternatif pemecahan masalah, maka langkah pertama pengembangan suatu inovasi didahului dengan pengenalan terhadap masalah. Identifikasi terhadap masalah inilah yang kemudian mendorong dilakukannya penelitian dan pengembangan (R\&D) atau evaluasi kurikulum, yang dirancang untuk menciptakan suatu inovasi. Dalam hal ini perlu untuk diperhatikan bahwa inovasi akan mempunyai makna jika inovasi tersebut diterapkan atau diadopsi, sebab jika inovasi tersebut tidak diterapkan/diadopsi/disebarluaskan maka inovasi tersebut hanya akan menjadi inovasi yang tidak terpakai. 
Pada kesempatan FGD ini, kita telah memformulakan berbagai persoalan. Maka sepantasnyalah kita mulai berbenah dengan situasi dan kondisi yang ada. Salah satunya adalah mau menerima perubahan dan belajar dari setiap perubahan. Seusai sesi pengantar dari pengabdi tersebut, kemudian dilanjutkan dengan sesi tanya jawab.

\section{Sesi Tanya Jawab Tentang Keunggulan Pengabdian}

Pada sesi ini, banyak guru yang bertanya tentang program apa yang akan dilakukan, termasuk sebagian diantara mereka belum begitu melek teknologi. Disesi kedua, para guru banyak bertanya tentang upaya yang dapat dilakukan agar dapat mengkulturalkan budaya inovatif dalam pendidikan. Kenapa, ya karena memang diakui bahwa mengajar bukan sumber utama penghidupan. Mengajar adalah sumber pendapatan lain.

Suasana FGD semakin bersemangat. Para guru semakin tertarik untuk bertanya langsung kepada pengabdi, termasuk kiranya pengabdi mau membantu guru untuk meningkatkan keterampilannya dalam mengoperasikan komputer lebih baik.

\section{Rencana pelaksanaan pelatihan perancangan perogram pengabdian.}

Seusai tanya jawab, pengabdi bersama guru membangun kesepakatan-kesepakatan tentang rencana pelatihan sesuai dengan hasil FGD. Untuk mengatasi kebingungan dan menampung rasa ingin tahu GURU, maka penting bagi fasilitator untuk menjelaskan keuntungan dari mengikuti pelatihan penyusunan perancangan sistem informasi berbasis web tersebut.

Dalam kegiatan sosialisasi ini tanpak semangat dan antusias para guru untuk melaksanakan kegiatan pelatihan. Berdasarkan hasil FGD pengabdi melakukan pemetaan dan bersama peserta melakukan kesepakatan tentang waktu pelaksanaan pengabdian, yang hasilnya Pengabdian direncanakan dilaksanakan pada tanggal 18-19 Agustus 2018.

\section{Pelatihan perancangan website sistem informasi akademik}

Pelatihan perancangan web dilaksanakan tanggal 18-19 Juli 2018. Kegiatan ini dihadiri oleh 40 peserta yang terdiri atas guru MTs. Nurul Muhsinin Batujai. Pelatihan ini dilaksanakan selama dua hari dengan mekanisme pengabdian sebagai berikut:

\section{Pengenalan struktur, tujuan, isi dan domain hosting}

Untuk kategori ini, maka komponen yang harus dipahami oleh tujuan sebenarnya dari pembuatan website. Apakah sebagai media presentasi atau pemasaran, sebagai media untuk melayani konsumen, sebagai media transaksi on-line. sebagai media informasi berita. Dengan mengenal tujuan ini, maka seorang perancang web dapat merancang web sesuai dengan yang ditujuankan. Dari hasil analisa tersebut, barulah kemudian kita merencanakan seperti apa sitemapnya dan struktur dari websitenya, serta penggunaan teknologi yang meliputi aplikasi, dan fitur-fitur lain yang akan ditempelkan dalam sebuah website. Hal ini tentu akan mempengaruhi kualitas dan kecepatan browsing pengunjung website nantinya.

\section{Menentukan isi website}

Selain tampilan, isi dari website juga harus diperhatikan. Dengan mengedepankan prinsip content is king, isi dari website adalah yang paling krusial karena melalui contentlah kita menyampaikan pesan komunikasi kepada khalayak sasaran yang menjadi pengunjung website. Karenanya kita harus memperhatikan kualitas copywriting, kualitas foto dan video yang 
dimasukkan kedalam sebuah website. Copywriting yang dipergunakan ada baiknya tetap mengikuti kaidah Search Engine Optimization.

\section{Menentukan target pengunjung}

Meskipun suatu website mempunyai sifat terbuka dalam arti sebuah website bebas dikunjungi oleh semua orang, namun alangkah baiknya apabila dalam pembuatan websiteperlu dilakukan gambaran target yang akan dituju oleh sebuah website. Alasan ini lebih didasarkan pada penggunaan hardware dan aplikasi browser yang berbeda dengan setiap pengunjung.

\section{Menetukan struktur website}

Struktur website diperlukan untuk memberikan kemudahan dalam mengelola suatu website. Tentunya struktur tersebut harus disesuaikan dengan isi dari website. Dengan memiliki struktur yang terorganisasi dengan baik, suatu website akan memberikan kemudahan dalam navigasi, editing dan pemeliharaan websi tersebut.

\section{Pembelian domain dan hosting}

Domain diibaratkan sebagai alamat. Tiap-tiap komputer yang berhubungan satu sama lain akan memiliki alamat IP (IP Address). Namun, alamat IP yang berbentuk deretan angka sulit untuk dihafalkan. Karenanya, muncul nama domain. Hosting diibaratkan sebuah lahan dimana Anda dapat membangun "rumah" di atasnya. Jika Anda memiliki nama domain namun tidak memiliki hosting, hal itu tampak seperti Anda memiliki alamat tanpa rumah. Anda dapat menarik pengunjung lewat nama domain, namun pengunjung takkan melihat apapun di sana. Dalam website tersebut, Anda dapat menyimpan informasi, file, atau bahkan database (baik berupa tulisan, gambar, script, video, dII) yang ingin ditampilkan. Sementara itu respon peserta terhadap penyampaian materi konsep tentang website beragam diantaranya adalah pernyataan sebagai berikut:

Indra Rusmala Dewi saat di wawancarai seuasai sesi pengenalan pertama menyampaikan "betapa kelihatan rumitnya memahami komponen-komponen pemograman website, sehingga memungkinkan bagi kita pemula memahami apa yang telah dipelajari. Sulit kalau mempelajari bahasa pemograman. Sebaiknya kami bukan di ajarkan tentang membuat websitenya melainkan menggunakan website-nya". Perasaan lain juga disampaikan oleh Faesal, bahwa belajar tentang website adalah ilmu komputer tingkat tinggi. Sulit menguasainya jika hanya diajarkan dalam beberapa kali. Kegiatan ini harus dijadikan sebagai kegiatan rutin dan berkelanjutan sehingga pengetahuan tersebut tidak terpotong ditengah jalan. Testimoni oleh Ibu Indra tersebut mengindikasikan bahwa pada dasarnya pengetahuan guru tentang website dan komponennya bukanlah hal yang mudah untuk diajarkan. Setidaknya kita harus memiliki pengetahuan awal yang cukup tentang dunia website, barulah kemudian dapat mengembangkannya. Pendapat di atas kemudian diperkuat oleh pendapat faesal sebagai berikut:

Website bukanlah barang yang mudah dibuat sebagaimana membuat grup whats up maupun facebook. Hanya membutuhkan beberapa persyaratan yang harus dipenuhi. Website begitu sulit untuk dibuat oleh orang yang sama sekali tidak faham dengan dunia pemrograman. Jangankan mau meramu website, mau mengelola blog saja sangat sulit, kecuali blog yang dikelola menyeseuaikan dengan website yang dibuat sehingga Nurul Muhsinin paling tidak memiliki sarana informasi yang akuntabel untuk menyampaikan informasi yang ada. 
Mardiana dalam sambutannya juga menyampaikan kegundahannya tentang website tersebut dan mengiyakan saran dan masukan bang Faisal bahwa jadikan kita sebagai pengguna buka makers. Terus terang kalau makers kami kesulitan, lebih-lebih diantara kami masih ada yang belum lancar mengoperasikan komputer. Oleh karena itu, kami siap belajar jika menjadi user.

Menangkap apa yang menjadi kegelisahan tersebut, bahwa langkah selanjutnya adalah bagaimana pertemuan pelatihan tersebut paling tidak dapat memberikan gambaran awal bagi guru tentang urgensi website dalam mempermudah sistem adminsitrasi. Walaupun merasa kesulitan, pengabdi juga senantiasa memberikan inovasi motivasi agar guru-guru terus meningkatkan pengembangan dirinya bukan berpangkutangan dengan ketidakbiasaannya.

\section{Merancang Web bersama}

Merancang WEB bersama merupakan kegiatan mendiskusikan tentang struktur isi web yang akan disajikan. Semua peserta membuat simulasi berdasarkan analisis kebutuhan selama melaksanakan tugas pengadministrasian, termasuk didalamnya memuat konten-konten yang ditampilkan, isinya apa saja dan bagaimana mekanisme kerjanya.

\section{Partisipasi dan Pelibatan Para Pihak}

Partisipasi dan pelibatan para pihak ditunjukkan dengan sikap kerjasama kepala madrasah, pimpinan yayasan dan para guru. Bentuk kerjasama ini dibuktikan dengan daya support yang luar biasa terhadap kegiatan pengabdian tersebut. Kepala Madrasah dan lainnya mendukung secara maksimal apa yang telah dilakukan oleh pengabdi selama melaksanakan pengabdian, mulai dari penelusuran program, perencanaan sampai pelatihan dan evaluasi.

\section{Pendampingan}

Pendampingan dapat dipahami sebagai kegiatan pemberdayaan masyarakat dengan menempatkan tenaga pendamping sebagai fasilitator, komunikator, motivator dan dinamisator. Pada dasarnya, pendampingan merupakan upaya untuk menyertakan masyarakat dalam mengembangkan berbagai potensi sehingga mampu mencapai kualitas kehidupan yang lebih baik. Selain itu diarahkan untuk memfasilitasi proses pengambilan keputusan yang terkait dengan kebutuhan masyarakat, membangun kemampuan dalam meningkatkan pendapatan, melaksanakan usaha yang berskala bisnis serta mengembangkan perencanaan dan pelaksanaan kegiatan partisipatif.

Prinsip Pendampingan Prinsip-prinsip pendampingan dalam upaya pemberdayaan masyarakat meliputi: pertama, Prinsip Spasial Lokal. Penguasaan dan pemahaman terhadap ruang, kondisi, potensi dan perkembangan keterampilan guru dan administratur lainnya. Kedua, Prinsip Berkelompok yaitu pendampingan secara berkelompok. Ketiga, Prinsip Keberlanjutan. Seluruh kegiatan penumbuhan dan pengembangan diorientasikan pada terciptanya sistem dan mekanisme yang mendukung pemberdayaan guru secara berkelanjutan. Berbagai kegiatan yang dilakukan merupakan kegiatan yang memiliki potensi berlanjut di kemudian hari.

Keempat prinsip tersebut kemudian di tranformasikan dalam kegiatan pengabdian di MTs. Nurul Muhsinin. Pendampingan berfunsgi untuk mengawal sejauhmana pemahaman guru tentang pelatihan yang telah dilaksanakan. Kegiatan pendampingan bertujuan untuk menguatkan pengalaman bagi guru untuk memahami secara mendalam tentang bagaimana mendesain web yang baik. 
Kegiatan pendampingan di MTs Nurul Muhsinin dilakukan melalui Pendampingan pemberian bantuan teknis tentang penyampaian dan penguatan materi sebelumnya. Materi pendampingan tidak jauh berbeda dengan materi saat pelatihan. Materinya menyangkut tentang hal-hal yang belum dipahami oleh guru selama melaksanakan pelatihan.

Kegiatan pendampingan dilakukan oleh fasilitator. Adapun sasaran pendampingan adalah semua guru yang pernah mengikuti pelatihan penyusunan dan analisis soal. Adapun tujuan pendampingan adalah untuk: (1) Memperkuat pemahaman dan membangun kepercayaan diri unsur-unsur sekolah dalam melaksanakan penilaian; (2) memperkuat keterlaksanaan penilaian yang akuntabel; (3) Membantu memberikan solusi kontekstual dalam menyelesaikan permasalahan yang dihadapi saat menyusun instrument penilaian; (4) Membangun kultur belajar sekolah melalui penerapan kurikulum secara inovatif, kontekstual, taat asas, dan berkelanjutan.

Pendampingan dilakukan oleh pengabdi bersama fasilitator. Namun sampai pengabdian ini diselesaikan belum ada yang mampu merancang web dengan benar. Oleh karena itu, beberapa hal yang dilakukan pengabdi untuk mengatasi persoalan tersebut diantaranya adalah:

1. Mengidentifikasi peserta pelatihan yang memiliki kemampuan lebih baik dibandingkan dengan temannya.

2. Mengundang peserta terpilih untuk mengikuti pendampingan khusus yang telah dipersiapkan oleh pengabdi.

3. Menentukan jam pelaksanaan pendampingan.

4. Melaksanakan pendampingan.

Berdasarkan proses pendampingan secara khusus dapat disampaikan tentang kemajuan guru dalam merancang website, namun secara langsung untuk pembuatan website secara mandiri, belum dapat merancang sendiri. Untuk itu, dikemudian hari kegiatan pelatihan merancang website dapat diagendakan dengan waktu yang lebih lama.

Berikut alur pendampingan yang dilakukan selama pelatihan pada kegiatan pengabdian:

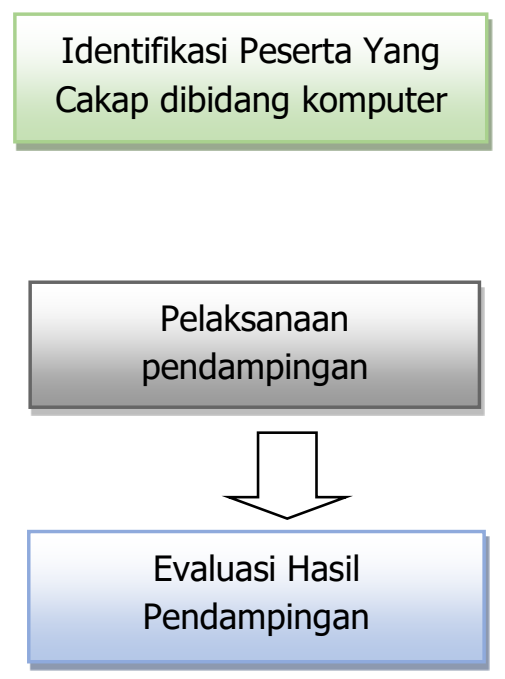



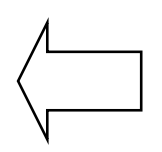

Menentukan jam pelaksanaan pendampingan

Kegiatan pendampingan ini dilaksanakan di MTs. Nurul Muhsinin Batujai dan dihadiri oleh 5 orang guru. Diantaranya guru Bahasa Inggris, Guru Matematika, Guru Aqidah Akhlaq, guru Bahasa Indonesia dan Kepala Sekolah. 


\section{Monitoring dan Evaluasi}

Monitoring program pengabdian masyarakat dilakukan dengan mengunjungi langsung lokasi pelaksanaan kegiatan pengabdian. Kegiatan monitoring yang dilakukan pengabdi hanya bersifat memotret, mencatat, mendengar dan menyaksikan apa yang dilakukan selama pelatihan ataupun pra pengabdian.

Kegiatan monitoring dilaksanakan tidak hanya pada saat pelatihan, tetapi pasca pelatihan. Pengabdi pada kesempatan ini tidak mengkoreksi proses pelatihan dan lainnnya melainkan pengabdi menganalisis keterlaksanaan program yang telah direncanakan.

Hasil monitoring menginformasikan bahwa pelaksanaan pengabdian berjalan sesuai dengan yang direncanakan. Pengabdian melalui proses pembelajaran, pelatihan walaupun outputnya belum maksimal. Kegiatan monitoring dihadiri oleh perwakilan Lembaga Penelitian dan penerbitan (LP2M) UIN Mataram. Perwakilannya mencatat dan mengamati pelaksanaan pengabdian yang telah dilaksanakan. Kegiatan monitoring dilaksanakan pada tanggal 19 Agustus 2018.

\section{Evaluasi kegiatan pengabdian}

Evaluasi dilakukan dengan menganalisis keterlaksanaan program yang sudah direncanakan dan dilaksanakan, ketercapaian tujuan yang dan upaya perbaikan berkelanjutan. Kegiatan evaluasi program pelatihan tidak hanya dilaksanakan pada akhir kegiatan program, tetapi sebaiknya dilakukan sejak awal, yaitu mulai dari penyusunan rancangnan program pelatihan, pelaksanaan program pelatihan dan hasil dari pelatihan. Selama melaksanakan monitoring dan evaluasi terdapat beragam kendala yang dihadapi diantaranya adalah penguasaan guru tentang komputer termasuk penguasaan tentang pemrograman masih minim. masih kurang. Namun faktor pendukungnya adalah semangat untuk belajar sangat tinggi hal ini teruji dari antusiasme guru mengikuti pelatihan.

Kegiatan evaluasi dilakukan pasca pelatihan dan pasca pendampingan serta rencana tindak lanjut. Hasil evaluasi pasca pelatihan menggambarkan bahwa kegiatan mendesain WEB bagi sebagian guru dirasa memang sulit, karena butuh ketelitian dan ketekunan, keuletan dan rasa ingin tahu yang tinggi. Selanjutnya, pasca pendampingan menjelaskan bahwa diakui memang sangat sulit, karena sulitnya, maka pengabdi melakukan pendampingan dalam kelompok kecil yang disesuaikan dengan strata skill komputer guru.

Hasil evaluasi menggambarkan bahwa pengabdian tentang perancangan WEB sebaiknya dilakukan dengan pendanaan yang cukup, dengan durasi pelatihan yang intens. Dengan demikian akan lebih mudah bagi pengabdi untuk memahami dan menguasai sistem perancangan web sistem informasi akademik.

\section{Kesimpulan}

Berdasarkan latar belakang dan pelaksanaan kegiatan di atas dapat disimpulkan sebagai berikut: Pelaksanaan pengabdian dilaksanakan dalam lima tahapan yaitu observasi, sosialisasi dan FGD, Pelatihan, monitoring dan evaluasi serta pendampingan, Pelaksanaan pengabdian tentang perancangan WEB sistem dinformasi akademik didukung oleh pimpinan madrasah, guru 
dan stakeholder lainnya yang mana pelaksanaannya berhasil meningkatkan pengetahuan dan pengalaman guru dalam merancang dan mendesain website walaupun tidak maksimal.

Beberapa kendala yang dihadapi dalam pelaksanaan pengabdian diantaranya adalah; minimnya pengetahuan guru tentang website, bahasa pemrograman dan pengetahuan tentang komputer. Adapun keunggulannya adalah motivasi dan antusiasme peserta sangat tinggi.

\section{Daftar Pustaka}

Arthur, J., Graigner, T \& Wray, D. Learning To Teach In The Primary School. (New York: Routledge, 2006).

Amirul Hadi dan Haryono, Metodologi Penelitian Pendidikan. (Bandung : Pustaka Setia, 2005).

Dea Yuzistin, Dindon Fiqri Aji \& Petrus Dwi Ananto Pamungkas, Sistem Informasi Administrasi Siswa Berbasis Website Pada Sma Islam Putradarma Bekasi , Bina Insani Ict Journal, Vol.3, No.1, Juni 2016, 253 - 268253 Issn: 2355-3421 (Print) Issn: 2527-9777 (Online 255)

Davis, D. (2000). Supporting Parent, Family, and Community Involvement in Your School. Northwest Regional Educational Laboratory, (1-39).

Jusak dalam Awad Achmad Hansyi, Titik Lusiani \& Teguh Sutanto, Rancang Bangun Sistem Informasi Administrasi Akademik Berbasis Web Dengan Menggunakan Xhtml (Studi Kasus Pada Sman 8 Surabaya), Sekolah Tinggi Manajemen Informatika \& Teknik Komputer Surabaya.

http://www.sumberpengertian.co/pengertian-sosialisasi-lengkap. diakses tanggal 05/10/2018. jam 21.17 WITA.

https://www.maxmanroe.com/vid/manajemen/administrasi-pendidikan.html.

Muhammad Nazar, Metode Penelitian. (Jakarta: Galih Indonesia, 1998).

http://irdaamir.blogspot.com/2015/12/urgensi-administrasi-pendidikan-dalam.html. diakses tanggal 7/11/2018 jam 7.19.

Kadek Wibowo, Penerapan Sistem Informasi Akademik Berbasis Web (Studi Kasus Mts. Maulana Ishaq Banyuwangi), Disampaikan Saat Seminar Nasional Inovasi Dan Tren (Snit) 2015.

The National Commission on Excellence in Education. (1983). A Nation at Risk: The Imperative for Educational Reform. A Report to the Nation and the Secretary of Education United States Department of Education: Washington.

Tidd, J. Innovation Models. (University Sussex, 2006).

UNESCO. (2006). Teachers and Educational Quality: Monitoring Global Needs For 2015. UNESCO Institute For Statistics: Canada.

Nancy Henderson, Henderson, N. (2011). Collaborative strategies to advancestudent learning. National Education Association. 1-77.

Mulyasa, Manajemen Berbasis Sekolah: Konsep, Strategi Dan Implementasi. (Bandung: Remaja Rosdakarya, 2007).

Hasbullah. Dasar-dasar ilmu pendidikan. (Jakarta: PT. Raja Grafindo Persada, 2011).

Suparlan. Guru Sebagai Profesi. (Yogyakarta; Hikayat, 2006).

Weis, Weiss, H. B., et al. (2009). Reframing family involvement in education:supporting families to support educational equity. Research Review No. 5 (1-52), 2009.

Wahyono, Teguh, S.Kom, M.M. Sistem Informasi, Konsep Dasar, Analisis Desain dan Implementasi. Jakarta: Cetakan Pertama. Graha Ilmu, 2004.

Kurniawan, Hadi. 2010. Pengertian Sistem Informasi Akademik. Diambil dari: http://tipstrategi.wordpress.com/2010/05/05/pengertian-sistem-informasi-akademik/. (23 November 2013). 